\title{
Assessing water conditions for Heleophryne rosei tadpoles and the conservation relevance
}

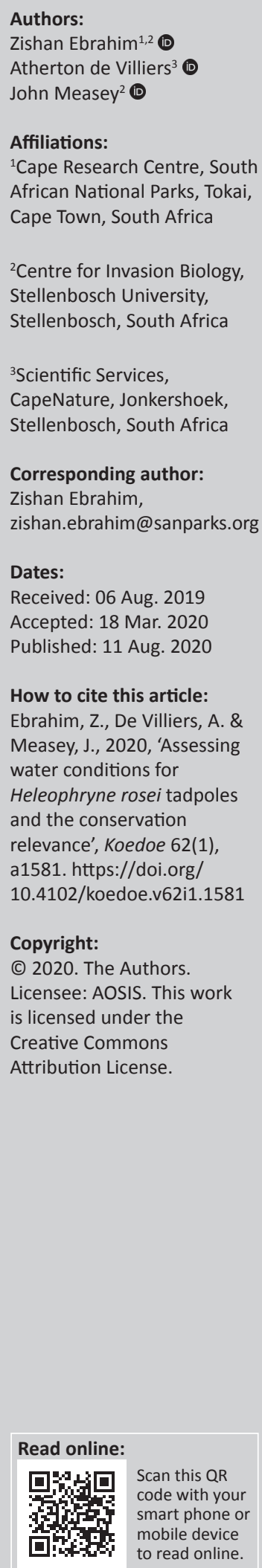

The Table Mountain Ghost Frog (Heleophryne rosei) is endemic to the Table Mountain massif and is Critically Endangered. Other than clear, clean perennial stream flow, the optimal aquatic conditions required by their larvae are unknown. Dissolved oxygen, temperature, $\mathrm{pH}$, electroconductivity, aspect and permanence of flow are the independent variables measured seasonally at two sampling altitudes at 12 rivers of the massif. Using a logistic regression model we found that a permanence of water flow and lower water temperature were significant predictors of tadpole presence. Streams with mean summer temperature above $17.2^{\circ} \mathrm{C}$, at $300 \mathrm{~m}-400 \mathrm{~m}$ above sea level, do not have tadpoles. Summer and autumn abstraction should be avoided, while a summer water temperature above an average of $17.2^{\circ} \mathrm{C}$ is a threshold of potential concern for management authorities responsible for biodiversity conservation, threat mitigation efforts, and bulk-water supply and abstraction.

Conservation implications: The Environmental Water Reserve has not been determined for streams of Table Mountain. The requirements of the Critically Endangered Table Mountain Ghost Frog (Heleophryne rosei) can be adopted as the minimum conditions to support this species and associated communities. Perennial flow, an average January water temperature of $17.2^{\circ} \mathrm{C}$ or lower.

Keywords: amphibian; environmental water reserve; management; protected areas; temperature; water flow.

\section{Introduction}

Southern Africa has a rich assemblage of anuran amphibians (South Africa has 12 families). Of these, one entire family is endemic to the southern African region (Poynton 1964): the ghost frog family, Heleophrynidae. These torrent-adapted species live in and around fast-flowing montane streams. Adults are cryptic, hiding in crevices and emerging at night, while tadpoles are relatively easy to find in streams and easily identified by their large, specially adapted oral suckers used for grazing on algae-covered rocks (Boycott 2004). The two genera of the ghost frog family contain seven species, one in the genus Hadromophryne (Natal cascade frog) and six in the genus Heleophryne (ghost frogs); the latter is confined to the Cape Fold Mountains (Channing, Boycott \& Van Hensbergen 1988) across south-west South Africa's winter rainfall region (Colville et al. 2014). The Table Mountain Ghost Frog, Heleophryne rosei, is confined to the Table Mountain massif (Boycott \& de Villiers 1986).

The extreme endemism of $H$. rosei (range $<10 \mathrm{~km}^{2}$ ), and a set of ongoing threats including invasive vegetation and habitat degradation (Boycott \& de Villiers 1986; ed. Measey 2011), have meant that it has long been considered Critically Endangered (South African Frog Re-assessment Group [SA-FRoG]; IUCN 2017). Ironically, it occurs only within areas protected by the South African National Parks (SANParks) and the South African National Biodiversity Institute (SANBI). Of the 12 streams draining off Table Mountain, only seven (counting Upper Disa and Lower Disa as two streams) are currently inhabited by tadpoles, but the species' past distribution has been larger (Boycott \& de Villiers 1986). Table Mountain has undergone many transformations, with the plateau holding several large dams; it was used as an alien timber plantation and subsequently cleared. The slopes are currently being cleared piecemeal of invasive acacias, pines and eucalypts (amongst others) (Cheney et al. 2019). Changes in flow regime and abstraction in the lower reaches of the mountain's rivers may have led to the loss of $H$. rosei tadpole habitat, but we are still largely ignorant of the physiological requirements of all ghost frog species. 
The variables $\mathrm{pH}$, salinity and water temperature are known to influence stream-breeding anurans with respect to metabolism, growth rates, emergence, fecundity and ultimately survival (Rivers-Moore \& Karssing 2014). Tadpole health may reflect total population health, as well as ecosystem resilience (McDiarmid \& Altig 1999). It is assumed that the larval stage of $H$. rosei lasts more than 12 months. This is based on congeneric assumptions, their observed occurrence only in sections of streams that are perennial (Boycott \& de Villiers 1986), and because two size cohorts are observed after the breeding and spawning season (ZE, AdV \& JM pers. obs.).

The aim of this study is to determine which of these water variables influence the presence or absence of $H$. rosei tadpoles. In addition, we discuss known threats to this species in relation to the findings of the study in order to infer conservation implications and management directions.

\section{Materials and methods Site description}

The Table Mountain massif is a sandstone ridge with granite outcrops, constituting the Northern Section of South Africa's Table Mountain National Park. Twelve streams flowing off the mountain were chosen for this study (Figure 1). Afromontane Forests are the natural riverine vegetation with adjacent Sandstone and Granite Fynbos (Mucina \& Rutherford 2006). The fynbos is fire-driven (Van Wilgen et al. 2010). Forests exclude small fires while anthropogenically altered landscapes alter fire return intervals (Slingsby et al. 2020). CapeNature, the nature conservation authority for the Western Cape Province, monitors H. rosei tadpole populations within the Table Mountain National Park and Kirstenbosch National Botanical Garden estate at the end of the southern summer (ed. Measey 2011; Measey et al. 2019), before the wet season. This allows for the greatest tadpole visibility during the lowest flow. This monitoring is through an annual timed (30 min) count on five streams at altitudes of about $300 \mathrm{~m}-$ $400 \mathrm{~m}$, and two streams at about $800 \mathrm{~m}$. The former, loweraltitudinal monitoring provides the presence/absence response variable for this study. SANParks, the conservation authority for national parks in South Africa, measures (in situ, seasonally) the water chemistry of selected streams within Table Mountain National Park in order to compare conditions where tadpoles are present/absent, controlled for altitudes of $300 \mathrm{~m}$ and $400 \mathrm{~m}$ above sea level.

\section{Water chemistry monitoring}

Habitat suitability for aquatic larvae is entirely dependent on water conditions. The variables measured in this study are a global standard for monitoring, and prescribed by SANParks' Biodiversity Monitoring System: the Freshwater and Estuarine Monitoring Programme (Russell, Roux \& Randall 2012). A hand-held, multi-probe, water chemistry instrument (models pH100, DO200, EC300; YSI, Yellow Springs Instrument, Yellow Spring, United States) was used. Monitoring began in the summer of 2014 (inclusive of the El Niño event), ending in autumn 2016. Measuring these variables in situ is cost-effective and convenient. Measurement was taken in the middle of a stream, mid-profile, after at least $10 \mathrm{~min}$ of stabilisation. The explanatory variables assessed in this study are: aspect, electro-conductivity (salinity), dissolved oxygen, $\mathrm{pH}$, water temperature, and permanence of water flow. Although this is not a comprehensive water analysis, these integrated metrics provide an overall indication of habitat health.

\section{Statistical analyses}

A stepwise linear regression was used to remove variables that do not explain observed presence/absence. Linear models are constructed using the retained explanatory variables. The binomial response variable (presence or absence) was tested for, while abundances are displayed in relation to the ecological boundary for the $H$. rosei tadpoles (Table 1). The log-likelihood of 15 models was derived, and Akaike's information criterion calculated (Akaike 1973). All analyses were conducted in R (R Core Team 2019).

\section{Results}

Tadpoles are found in water with an annual mean temperature from $13.4{ }^{\circ} \mathrm{C}$ to $14.1{ }^{\circ} \mathrm{C}$ (10 consecutive seasons), rising to a summer mean temperature of $16.2^{\circ} \mathrm{C}-17.2{ }^{\circ} \mathrm{C}$ (mean of three consecutive summer seasons). Three variables best predict the presence of $H$. rosei tadpoles below the Table Mountain plateau: the three interacting effects of a stream's permanence of flow, mean water temperature, and electro-conductivity (Table 1). The two best models have a difference in Akaike's information criterion of less than two, thus the model with the lowest number of parameters is preferred (Anderson \& Burnham 2002). The lower the water temperature, the more likely it is that tadpoles are present. Permanent water flow is essential for tadpoles. The discerning effect of electro-conductivity is least significant, yet positive, indicating that higher conductivity is preferred, but lower conductivity still tolerated, by tadpoles. With this regression model, over $60 \%$ of the variance in the dataset is explained by these three variables $\left(R^{2}=0.602\right)$. Only permanence of flow and mean temperature are significant contributors to this and to the state of the dependent variable $(p<0.001)$. Four of the five extant streams had constantly flowing surface water at both measured altitudes during all four seasons (Table 2, where $n=10$ ). Nursery Ravine, much like Cecelia Stream, had no surface flow for large sections below the $400 \mathrm{~m}$ contour during spring and summer.

\section{Discussion}

Results suggest that permanence of water flow, and low water temperature, are the best habitat predictors for the presence of $H$. rosei tadpoles; more so than electroconductivity, aspect, and the other variables measured. The data (for summer) suggest that an upper bound of a putative temperature envelope for $H$. rosei tadpoles is $17.2^{\circ} \mathrm{C}$. The lower end of the temperature envelope cannot be measured in situ as it is not likely to be reached naturally. 
TABLE 1: Four variables were considered for Linear Models.

\begin{tabular}{|c|c|c|c|c|c|}
\hline Models & Consider model B: & Log likelihoods & Number of parameters & $\Delta \mathrm{AICs}$ & Akaike weight \\
\hline A & $\begin{array}{l}\text { Mean temperature } \dagger \text {, Mean electro- } \\
\text { conductivity } \ddagger \text { and Permanence of stream } \S \text {, } \\
\text { Aspect }\end{array}$ & -2.5784 & 8 & 0.00000 & 0.52693 \\
\hline B & $\begin{array}{l}\text { Mean temperature } \dagger \text {, Mean electro- } \\
\text { conductivity } \ddagger \text { and Permanence of stream } \S\end{array}$ & -5.9015 & 5 & 0.64620 & 0.38145 \\
\hline C & Mean temperature and Permanence of stream & -8.9415 & 4 & 4.72615 & 0.04960 \\
\hline D & $\begin{array}{l}\text { Mean temperature, Aspect and Permanence of } \\
\text { stream }\end{array}$ & -6.1528 & 7 & 5.14883 & 0.04015 \\
\hline E & Permanence of stream & -14.6036 & 3 & 14.05050 & 0.00047 \\
\hline $\mathrm{F}$ & Aspect and Permanence of stream & -11.8493 & 6 & 14.54186 & 0.00037 \\
\hline G & Mean temperature & -15.1089 & 3 & 15.06099 & 0.00028 \\
\hline $\mathrm{H}$ & $\begin{array}{l}\text { Permanence of stream and Mean } \\
\text { electro-conductivity }\end{array}$ & -14.5558 & 4 & 15.95474 & 0.00018 \\
\hline । & $\begin{array}{l}\text { Permanence of stream, Aspect, and Mean } \\
\text { electro-conductivity }\end{array}$ & -11.8339 & 7 & 16.51099 & 0.00014 \\
\hline J & $\begin{array}{l}\text { Mean temperature and Mean } \\
\text { electro-conductivity }\end{array}$ & -15.1054 & 4 & 17.05392 & 0.00010 \\
\hline K & Aspect & -14.1983 & 5 & 17.23973 & 0.00010 \\
\hline L & Mean electro-conductivity & -16.2959 & 3 & 17.43499 & 0.00009 \\
\hline M & Aspect and Mean temperature & -13.9862 & 6 & 17.61188 & 0.00008 \\
\hline $\mathrm{N}$ & Mean electro-conductivity and Aspect & -13.9862 & 6 & 18.81569 & 0.00004 \\
\hline 0 & $\begin{array}{l}\text { Mean temperature, Aspect, and Mean electro- } \\
\text { conductivity }\end{array}$ & -13.3607 & 7 & 19.56459 & 0.00003 \\
\hline
\end{tabular}

The top model (A) includes all four variables. The second model (model B, in bold) is preferred as it has the least parameters within a $\triangle$ AIC of 2 (Anderson \& Burnham 2002). The standard error 0.344 on 19 degrees of freedom; $r$-squared $=0.602 ; f=9.579 ; p=0.000457$.

The preferred model includes these three variables: $\dagger$, Mean temperature; $\$$, Electro-conductivity; $\S$, Permanence of stream flow.

TABLE 2: The mean summer and mean annual temperatures (2014-2016), indicating permanence of flow ( $n=3$ and $n=10$ respectively)

\begin{tabular}{|c|c|c|c|c|c|c|c|}
\hline Stream name & $\begin{array}{l}\text { Tadpole presence/ } \\
\text { absence }\end{array}$ & Water use/management & Aspect & $\begin{array}{l}\text { Tadpole relative } \\
\text { abundance }\end{array}$ & Site altitude & $\begin{array}{l}\text { Annual mean temp } \\
\qquad\left({ }^{\circ} \mathrm{C}\right)\end{array}$ & $\begin{array}{c}\text { Summer mean } \\
\left({ }^{\circ} \mathrm{C}\right)\end{array}$ \\
\hline \multirow[t]{2}{*}{ Newlands } & Absent & Limited/past use & East & Absent & NL300 & $15.5(n=10)$ & $18.0(n=3)$ \\
\hline & & & & & NL400 & $12.8(n=6)$ & $16.4(n=2)$ \\
\hline \multirow[t]{2}{*}{ Fernwood } & Absent & Limited/past use & East & Absent & FW300 & $14.6(n=10)$ & $16.4(n=3)$ \\
\hline & & & & & FW400 & $12.2(n=5)$ & $0.0(n=0)$ \\
\hline \multirow[t]{2}{*}{ Hiddingh } & Absent & Abstraction/diversion & East & Absent & HR300 & $14.9(n=10)$ & $17.9(n=3)$ \\
\hline & & & & & HR400 & $11.3(n=1)$ & $0.0(n=0)$ \\
\hline \multirow[t]{2}{*}{ Kasteelspoort } & Absent & Water input/IBT & West & Absent & KS300 & $15.8(n=9)$ & $18.4(n=2)$ \\
\hline & & & & & KS400 & $14.3(n=6)$ & $0.0(n=0)$ \\
\hline \multirow[t]{2}{*}{ Blinkwater } & Absent & (Sub-surface flow assumed) & West & Absent & BK300 & $15.8(n=7)$ & $19.9(n=1)$ \\
\hline & & & & & BK400 & $0.0(n=0)$ & $0.0(n=0)$ \\
\hline \multirow[t]{2}{*}{ Platteklip } & Historical records & Weirs (limited use) & North & Absent & PG300 & $18.5(n=10)$ & $22.4(n=3)$ \\
\hline & & & & & PG400 & $16.6(n=10)$ & $18.8(n=3)$ \\
\hline Cecelia & Historical records & Abstraction/diversion & East & Absent & CR300 & $14.4(n=10)$ & $17.0(n=3)$ \\
\hline \multirow[t]{2}{*}{ Nursery } & Present & Abstractions@weir & East & 0.055 & NR300 & $12.0(n=4)$ & $0.0(n=0)$ \\
\hline & & & & & NR400 & $13.5(n=10)$ & $16.6(n=3)$ \\
\hline \multirow[t]{2}{*}{ Window } & Present & Abstractions@ @eir & East & 0.748 & WG300 & $13.6(n=10)$ & $16.8(n=3)$ \\
\hline & & & & & WG400 & $13.4(n=10)$ & $17.1(n=3)$ \\
\hline \multirow[t]{2}{*}{ Skeleton } & Present & Abstractions & East & 0.902 & SG300 & $13.9(n=10)$ & $16.9(n=3)$ \\
\hline & & & & & SG400 & $13.5(n=10)$ & $16.3(n=3)$ \\
\hline \multirow[t]{2}{*}{ Disa original } & Present & Dammed/IBT/abstraction & West & 0.921 & DO300 & $14.1(n=10)$ & $16.2(n=3)$ \\
\hline & & & & & DO400 & $14.1(n=10)$ & $16.8(n=3)$ \\
\hline \multirow[t]{2}{*}{ Disa (gorge) } & Present & Dammed/IBT/abstraction & South & 1.000 & DS300 & $14.1(n=10)$ & $17.2(n=3)$ \\
\hline & & & & & DS400 & $13.9(n=10)$ & $17.1(n=3)$ \\
\hline
\end{tabular}

The putative temperature-extreme boundary is $17.2^{\circ} \mathrm{C}$. The summer mean is proposed as a temperature threshold. These limitations are mapped as the threat of drought (too dry) and extreme temperatures (too warm) in Figure 1.

\section{Permanence of water flow in Table Mountain Rivers}

Water yield and water temperature are known to be influenced by land-use practices (Bosch \& Hewlett 1982) that affect adjacent riparian vegetation cover and fluvial connectivity, and they are also affected by water abstraction and water storage (Baxter 1977; Cooper et al. 2013; Davies \& Day 1998). Both no-flow of water and water of too high a temperature are indicative of habitatdisconnect.

Nursery Ravine, Cecelia Ravine and Fernwood Gully each have only one of two altitudes with favourable conditions 
for tadpoles. Of these, Nursery Ravine is the only stream that supports tadpoles in the 21st century. Much like Cecelia Ravine, adverse conditions are most likely due to lack of water flow rather than higher temperatures.

\section{Dams and water management}

Dams transform and flood lotic stream habitats, and divide continuous rivers. Regulation may allow for cooler summer water temperatures below the dam wall compared to if the dam were absent (Baxter 1977), while supplementing summer flow when water is released unseasonably, but this may cause other problems if there are regular releases of high water volumes over a short time. The waters of Disa Stream flow permanently even though water is diverted from above the study sites westward through the Twelve Apostles Tunnel. Water that would have naturally flowed east, to reach Cecelia (and Spilhaus, Rooikat) ravine, is dammed on the plateau (Victoria and Alexandra dams) and directed south-westwards via the De Villiers Dam. The Alexandra Dam's excess waters could best be utilised for a restorative ecological experiment: returning water volumes to the Cecelia/Rooikat streams (see the bypass between dam no. 5 and dam no. 3 in Figure 1). The Kirstenbosch Reservoir stores water abstracted from the weirs on Window Gorge and Nursery Ravine, which siphon off much of the summer flow, such that there is reduced tadpole habitat below both weirs (AdV \& ZE pers. obs.). Water abstractions should be limited to below the habitat of this species.

\section{Pine plantations}

The Table Mountain plateau was initially felled of plantations in the 1970s and 1980s, in a phased harvest (Van Wilgen 1996). Table Mountain Ghost Frogs still breed there today, even though pines are still present at low densities. However, it is unknown whether tadpole numbers have improved since then, as CapeNature's systematic $H$. rosei tadpole monitoring programme only started in 2003. Table Mountain National Park is removing pine plantations from the Tokai and Cecelia forests in a piecemeal fashion. An increase in water yield would be a positive sign of habitat rehabilitation (Bosch \& Hewlett 1982).

\section{Fire, erosion, and siltation threat}

Fires do not occur frequently through $H$. rosei stream habitats, even though frequent fire is listed as a potential threat to H. rosei (South African Frog Re-assessment Group [SA-FRoG], IUCN 2017). Fire is naturally excluded by Afromontane forest vegetation, but frequent fires do occur at the urban edge of Table Mountain National Park. Much of the fynbos covered Back (south) Table and Table Mountain Plateau has not burned for over six decades (Pooley 2014). Table Mountain National Park attempts to mimic natural fire cycles through ecologically prescribed piecemeal burning of senescent vegetation (Slingsby et al. 2020). Siltation has been regarded as a threat to frogs of the family Heleophrynidae (De Villiers 2004; Minter 2004). One stream with a seemingly consistent anthropogenic sand-input is Skeleton Gorge. This is because of a dune that formed from weathered sandstone off the bottom of the Hely-Hutchinson reservoir. Dune stabilisation is the only viable mitigation. Erosion and siltation monitoring should include fixed-point photography to determine rates of change and whether improvements are being made.

\section{Temperature}

Re-colonisation of $H$. rosei tadpoles in the streams of Cecelia Ravine would represent an indication for successful rehabilitation of that system, but this has not yet occurred. The average summer temperature for the Cecelia/Spilhaus stream is $17.0^{\circ} \mathrm{C}$; however, the summer of $2015 \mathrm{had}$ an average of $17.4^{\circ} \mathrm{C}$. Presumably this stream was cooler in the past if greater volumes of water flowed through it then.

Factors influencing water temperature are flow rate and the presence of dams. Both tributaries of the Disa River, Disa Stream (in Disa Gorge) and Original Disa Stream, flow from dams. The precautionary approach should apply in this regard: release of cooler (hypolimnion) waters is preferred, rather than the over-flow of warmer surface waters (from the epilimnion). The mean water temperature of mountain streams is expected to increase, largely due to increased air temperature attributed to climate change (Isaak et al. 2012).

Riparian vegetation has a cooling effect on the water in the adjoining stream (Davies \& Day 1998). The Table Mountain Ghost Frog is associated with Afromontane forests. These forests have shrunk from their pre-colonial extents (Sim 1907), but have rebounded on the southern slopes of Table Mountain (Poulsen \& Hoffman 2015). The latter authors suggest that in the past the indigenous forest canopy was significantly greater than its current extent, and the rebound is limited to the southern slopes of Table Mountain. Campbell and Moll (1977) show that the Platteklip and Kasteelspoort (Valley of the Red Gods) streams flowed under the cover of indigenous trees (circa 1600s) for much of their length. Mitigation of high temperatures could include the arrest of energy (heat) inputs through the restoration of indigenous forest canopies for cooling and shade.

\section{Conclusion}

The extent of expansion of the Table Mountain Ghost Frog's reproductive metapopulations may be predicted based on suitable tadpole habitat. The environmental reserve (of water) is a legal obligation, but it has not been determined for rivers in the study area. The flow requirements of a Critically Endangered freshwater species may be useful as a proxy for the environmental reserve. Environmental water (flow) requirements may not be met (for $H$. rosei tadpoles) in Cecelia Ravine, possibly due to pine plantations and a water bypass between the Alexandra and DeVilliers dams (Figure 1). Nursery Ravine is the extant stream in which the observed presence of $H$. rosei tadpoles is lowest (ZE \& AdV pers. obs.). Cecelia and streams with abstractive weirs should be prioritised for intervention. 


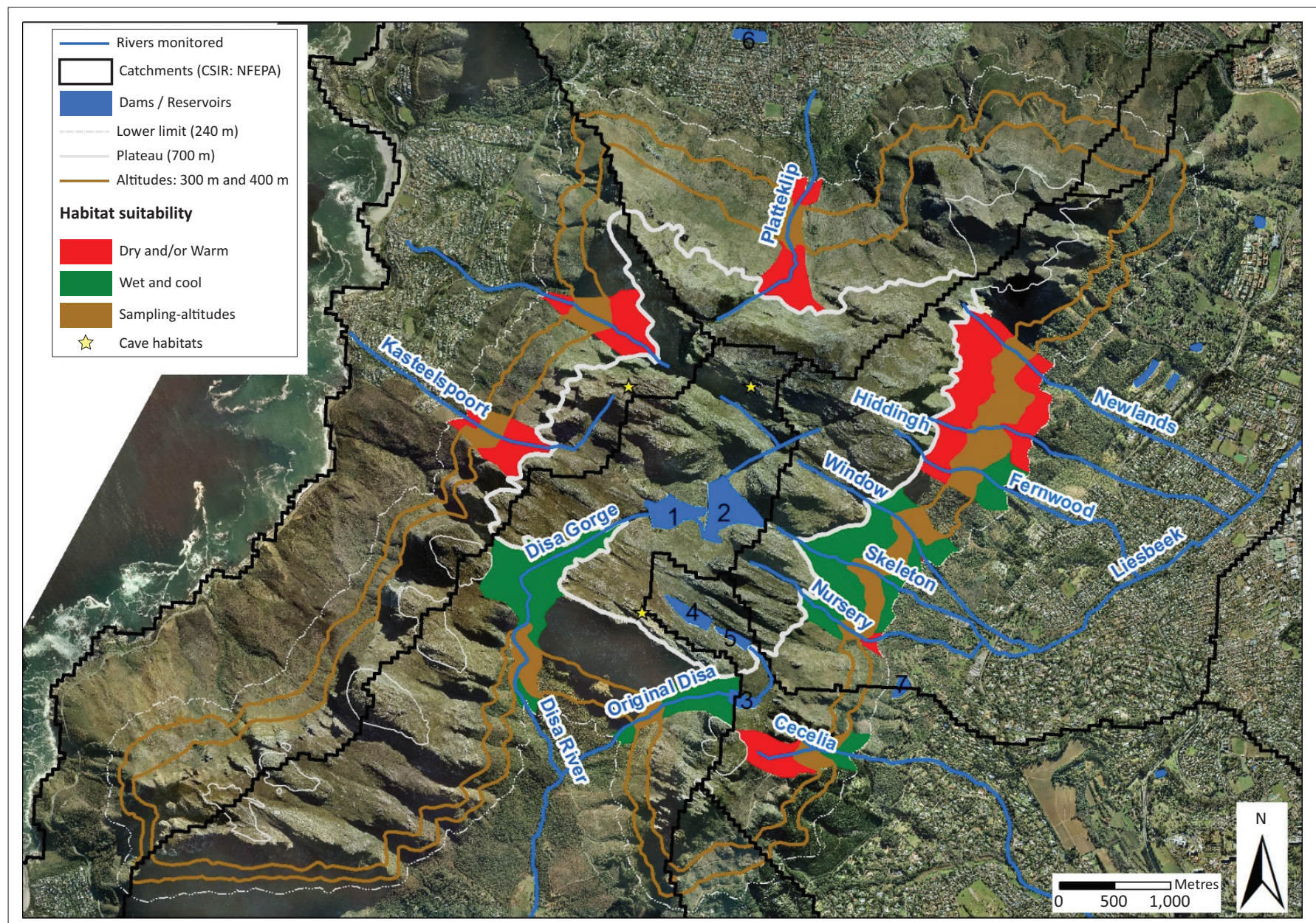

FIGURE 1: Findings of this study are extrapolated for each stream between the lower limit of the species and the massif's plateau. Water temperature and water flow results are mapped as 'Dry' to represent 'Drought' and 'Warm' to represent 'temperature extremes', interpolated for $400 \mathrm{~m}$ and above (to the plateau at $700 \mathrm{~m}$ ), and for $300 \mathrm{~m}$ and below (to $200 \mathrm{~m}$ ). Green areas are favourable for tadpoles as water conditions are both below a summer mean temperature of $17.2^{\circ} \mathrm{C}$ and water flows during all four seasons. The red bands indicate where water conditions are either above a summer mean temperature of $17.2^{\circ} \mathrm{C}$ or water stops flowing during at least one season, or both, i.e. unfavourable for tadpoles. The yellow star represents adult cave habitats (Gow 1963; Poynton 1964). Five dams on Table Mountain act as water reservoirs, (1) Woodhead, (2) Hely-Hutchinson, (3) De Villiers, (4) Victoria, and (5) Alexandra. While two reservoirs, (6) Molteno and (7) Kirstenbosch, are situated away from rivers. Contour-lines and river-lines are sourced from the National Geo-Spatial Institute of the Department of Land Affairs and Rural Development. Catchments were calculated by the Council for Scientific and Industrial Research (CSIR).

\section{Recommendations}

In addition to existing measures (e.g. alien clearing), two actions to mitigate temperature extremes and droughts could be considered: (1) Streams can be shaded by rehabilitating natural vegetation (through a properly managed burn cycle, not manual planting), and (2) the environmental water reserve should be determined, met and/ or mitigated, by supplementing water inputs (to the upper catchment) where possible, and by limiting water abstractions to an altitude below that used by $H$. rosei tadpoles. There is no forum currently to debate solutions. The City of Cape Town, CapeNature, Kirstenbosch Botanical Gardens, and SANParks (and perhaps the national and provincial authorities that issue water-use licenses) need to be open to options and innovations regarding water resilience, research and monitoring.

A Cape Peninsula freshwater conservation forum would be helpful toco-ordinateconservation and freshwater management, not only for human needs but for freshwater biodiversity and ecosystem functionality as well. CapeNature, South African National Biodiversity Institute and Table Mountain National
Park should co-ordinate non-invasive tadpole surveys and water chemistry monitoring more than once a year; perhaps on consecutive days, and weeks apart. The mimicry of natural firereturn cycles in an appropriate, controlled manor is needed to rehabilitate the upper catchment area of the Table Mountain plateau. Supplementation of water as a mitigation measure is conceivable for Cecelia Ravine if some waters of the Victoria and Alexandra dams are not diverted to the De Villiers Dam, but rather left on their original eastward course towards Cecelia and Rooikat ravines. The Cecelia/Rooikat streams, Nursery stream, and the Front and Back Table (north and south plateau) are the sources of four of Cape Town's rivers. These four streams represent four approaches to water course rehabilitation (in addition to alien clearing): reservoir-overflow diversion for environmental water requirements (Cecelia/Rooikat is the source of the Zand River catchment), mitigation of waterabstraction from small catchments (Nursery is the source of the Liesbeek River catchment), indigenous shading-plant rehabilitation (Platteklip is the source of the pre-colonial - now subterranean - Camissa River), and ecological burns (the Back Table is the source of the Disa River). 


\section{Acknowledgements Competing interests}

The authors declare that they have no competing interests.

\section{Authors' contributions}

Z.E. and J.M. conceptualised the article and attended to data analysis. Z.E. and A.d.V. were responsible for data collection. Z.E., A.d.V. and J.M. wrote the article.

\section{Funding information}

Funding for this article were received from A.W. Mellon Foundation, Department of Science and Innovation-National Research Fund (DSI-NRF), Centre of Excellence for Invasion Biology at Stellenbosch University, South African National Parks and CapeNature.

\section{Data availability statement}

The data is available in the SANParks Data Repository, CC BY 3.0.

\section{Disclaimer}

The views and opinions expressed in this article are those of the authors and do not necessarily reflect the official policy or position of any affiliated agency of the authors

\section{References}

Akaike, H., 1973, 'Maximum likelihood identification of Gaussian autoregressive moving average models', Biometrika 60(2), 255-265. https://doi.org/10.1093/ biomet/60.2.255

Anderson, D.R. \& Burnham, K.P., 2002, 'Avoiding pitfalls when using informationtheoretic methods', The Journal of Wildlife Management 66(3), 912-918. https:// doi.org/10.2307/3803155

Baxter, R.M., 1977, 'Environmental effects of dams and impoundments', Annual Review of Ecology and Systematics 8, 255-283. https://doi.org/10.1146/annurev. Review of Ecology and
es.08.110177.001351

Bosch, J.M. \& Hewlett, J.D., 1982, 'A review of catchment experiments to determine the effect of vegetation changes on water yield and evapotranspiration', Journal of Hydrology 55(1-4), 3-23. https://doi.org/10.1016/0022-1694(82)90117-2

Boycott, R.C., 2004, 'Genus Heleophryne Sclater, 1898 (Family Heleophrynidae)', in Minter, L.R., Burger, M., Harrison, J.A., Braack, H.H., Bishop, P.J. \& Knoepfer, D. Atlas and Red Data Book of frogs of South Africa, pp. 95-97. SI/MAB Series No.9, Smithsonian Institution Press, Washington DC

Boycott, R.C. \& de Villiers, A.L., 1986, 'The status of Heleophryne rosei Hewitt (Anura: Leptodactylidae) on Table Mountain and recommendations for its conservation' South African Journal of Wildlife Research 16(4), 129-134.

Campbell, B.M. \& Moll, E.J., 1977, 'The Forest Communities of Table Mountain, South Africa', Vegetatio 34(2), 105-115. https://doi.org/10.1007/BF00054478

Channing, A., Boycott, R. \& Van Hensbergen, H.J., 1988, 'Morphological variation of Heleophryne tadpoles from the Cape Province, South Africa (Anura: Heleophrynidae)', Journal of Zoology 215(2), 205-216. https://doi.org/10.1111/j 1469-7998.1988.tb04895.x
Cheney, C., Esler, K. J., Foxcroft, L. C., \& van Wilgen, N. J. 2019, 'Scenarios for the management of invasive Acacia species in a protected area: Implications of clearing efficacy', Journal of Environmental Management 238, 274-282. https:// clearing efficacy, Journal of Environmental
doi.org/10.1016/j.jenvman.2019.02.112

Colville, J.F., Potts, A.J., Bradshaw, P.L., Measey, G.J., Snijman, D., Picker, M.D. et al., 2014. 'Floristic and faunal Cape biochoria: Do they exist?', in N. Allsopp, J.F. Colville, G.A. Verboom (eds.), Fynbos: Ecology, evolution and conservation of a megadiverse region, pp. 73-93, Oxford University Press, USA.

Cooper, S. D., Lake, P. S., Sabater, S., Melack, J. M., \& Sabo, J. L., 2013, 'The effects of land use changes on streams and rivers in mediterranean climates', Hydrobiologia 719(1), 383-425. https://doi.org/10.1007/s10750-012-1333-4

Davies, B. \& Day, J., 1998, Vanishing waters, University of Cape Town Press, Cape Town.

De Villiers, A., 2004, 'Species account: Heleophryne rosei (Hewitt, 1925)', in Minter, L.R., Burger, M., Harrison, J.A., Braack, H.H., Bishop, P.J. \& Knoepfer, D., Atlas and red data book of the frogs of South Africa, Lesotho and Swaziland, pp. 108-111. $\mathrm{SI} / \mathrm{MAB}$ Series No.9, Smithsonian Institution Press, Washington DC.

Gow, C.E., 1963, 'Notes on the habitat of Heleophyrne rosei', African Wildlife 17, $113-116$.

Isaak, D. J., Wollrab, S., Horan, D., \& Chandler, G., 2012, 'Climate change effects on stream and river temperatures across the northwest US from 1980-2009 and implications for salmonid fishes', Climatic Change 113(2), 499-524. https://doi. org/10.1007/s10584-011-0326-z

IUCN SSC Amphibian Specialist Group, South African Frog Re-assessment Group (SA-FRoG), 2017. Heleophryne rosei. The IUCN Red List of Threatened Species 2017: e.T9773A13015448, veiwed 14 October 2017 from https://doi.org/10.2305/ IUCN.UK.2017-2.RLTS.T9773A77164671.en.

McDiarmid, R.W. \& Altig, R., 1999, Tadpoles: The biology of anuran larvae, University of Chicago Press. Chicago.

Measey, G.J. (ed.), 2011, Ensuring a future for South Africa's frogs: A strategy for conservation research. SANBI Biodiversity Series 19. South African National Biodiversity Institute, Pretoria.

Measey, J., Tarrant, J., Rebelo, A., Turner, A., du Preez, L., Mokhatla, M. et al, 2019, 'Has strategic planning made a difference to amphibian conservation research in South Africa?', Bothalia 49(1), 1-13. https://doi.org/10.4102/abc. v49i1.2428

Minter, L.R., Burger M., Harrison J.A., Braack H.H., Bishop P.J. \& Kloepfer D. (eds.) 2004, Atlas and red data book of the frogs of South Africa, Lesotho, and Swaziland. SI/MAB Series No.9, Smithsonian Institution Press, Washington DC.

Mucina, L. \& Rutherford, M.C. (ed.), 2006, The vegetation of South Africa, Lesotho and Swaziland. Strelitzia 19. South African National Biodiversity Institute, Pretoria.

Pooley, S., 2014, Burning Table Mountain: An environmental history of fire on the Cape Peninsula. Palgrave Macmillan, London.

Poulsen, Z.C. \& Hoffman, M.T., 2015, 'Changes in the distribution of indigenous forest in Table Mountain National Park during the 20th Century', South African Journal of Botany 101, 49-56. https://doi.org/10.1016/j.sajb.2015.05.002

Poynton, J.C., 1964, Amphibia of southern Africa; a faunal study. Annals of the Natal Museum 17. Natal Museum, Pietermaritzburg.

$\mathrm{R}$ Core Team, 2019, R: A language and environment for statistical computing, $\mathrm{R}$ Foundation for Statistical Computing, Vienna.

Rivers-Moore, N.A. \& Karssing, R.J., 2014, 'Water temperature affects life-cycle duration of tadpoles of Natal cascade frog'. African journal of aquatic science, 39(2), 223-227.

Russell, I., Roux, D. \& Randall, R., 2012, 'Biodiversity Monitoring Programme: Freshwater and Estuarine ecosystems', South African National Parks, Skukuza.

Sim, T.R., 1907, Forests and forest flora of the colony of the Cape of Good Hope. Taylor \& Henderson, Aberdeen.

Slingsby, J. A., Moncrieff, G. R., Rogers, A. J., \& February, E. C., 2020, 'Altered ignition catchments threaten a hyperdiverse fire-dependent ecosystem', Global Change Biology, 26(2), 616-628.

Van Wilgen, B.W., 1996, 'Management of the natural ecosystems of the Cape Peninsula: Current status and future prospects', Biodiversity \& Conservation 5(5), 671-684. https://doi.org/10.1007/BF00137614

Van Wilgen, B.W., Forsyth, G. G., De Klerk, H., Das, S., Khuluse, S., \& Schmitz, P., 2010, 'Fire management in Mediterranean-climate shrublands: A case study from the Cape fynbos, South Africa', Journal of Applied Ecology 47(3), 631-638. https://doi. org/10.1111/j.1365-2664.2010.01800.x 